\title{
Relation between Revenue and Expenditure of Union Budget: A Study
}

\author{
P Sai Harsha ${ }^{1}$, Mrs. Jyothi Mehra ${ }^{2}$ \\ ${ }^{1}$ Student of M.Com, Bhavan's Vivekananda College of Science, Humanities and Commerce, Sainikpuri, Secunderabad. \\ ${ }^{2}$ Assistant Professor in Department of Commerce, Bhavan's Vivekananda College of Science, \\ Humanities and Commerce, Sainikpuri, Secunderabad.
}

\begin{abstract}
The Union Budget is the important tool used by Government to analyze the financial position of the country. The present study will analyze the Trends of the expenditure budget for 6 different sectors for the last 5 years. Aim and Objective: To calculate the trend in the union budget towards expenditure of selected sectors for last 5 years, to calculate the trend in the union budget towards expenditure of selected sectors for last 5 years.

Methods: Correlation analysis, Trend analysis, comparative analysis.

Conclusion: - The study is conducted and observed that defence and home affairs sectors have the highest allocation and the education is the least and agriculture sector has an increasing trend from 2018-2021.
\end{abstract}

Key Words: Expenditure and Receipts Budget, Budgeted and Actuals, PM Kisan Yojana.

\section{INTRODUCTION}

Finance is an integral part of any institution to run its administration. Running of public administration is not an exception to this. Mahatma Gandhi in his works on "Ram Rajya", emphasized the reciprocal obligation of the ruler on the ruled. In Ram Rajya he stressed upon the need for generation of revenue by the ruler and the same shall be appropriated for welfare of the citizens of the country. In the same way, Prof. A.C. Pigou in his book 'Welfare Economics' advocated the need for levying of taxes as a source of public revenue for meeting public expenditure Budget documents are not just numbers. Analyzing them one can understand the intention of the government, its priorities, policies and allocation of financial resources, among different regions \& industries. No system of federation can be successful unless both union and the states have at their disposal adequate financial resources to enable them to discharge their respective responsibilities under the constitution.

Union budget is prepared by analysing various situations and by conducting various meetings with the panel and will be presented in the parliament. In the budget all the Revenue receipts and the allocations of various sectors are prepared. As per the RBI (Reserve bank of India), "Development expenditure leads to creation of human capital and general economic assets". Usually development expenditures include Expenditures related to social and economic services. Non development expenditures comprise of expenditures under General Services.

\section{REVIEW OF LITERATURE:}

Hicks. V.K (1955) "Public Finance", James Nisbet \&Co. Cambridge, analyzed the classification of Government budget and its necessity. He only discussed the budget proposal of the Government and its allocation.

Pigou. A.C in his book named "The Range of Government Expenditure"(1973) made description of the different expenditure made by Government of India in plan and non-plan expenditure and their comparison in the different years of each department.

Medhi, Nripendra Nath explained in their research "A study on Revenue receipts and Revenue expenditure of the government of ASSAM "has highlighted the various revenue receipts and revenue expenditure that are allocated in the budget assembly of the Assam state. The major findings of this thesis were : There is an increasing trend in the cash balance investments by the people of Assam, tax revenue is major and most dependable source of revenue earning among all sources of the Government of Assam, 6 In interim period of the study, the government earned tax revenue less than the budget target, The majority amount of the revenue expenditure is incurred for the development expenditure, The budgetary grant for Medical and Public Health found satisfactory about $4 \%$ average every year during study period but in the percentage out of total grants it was gradually reduced and later period it has enhanced up to $5 \%$. 
Vol. 8, Issue 11, November 2021

DOI: $10.17148 /$ IARJSET.2021.81105

In the Ph.D. dissertation (2004) of Prasanta Sarma entitling the "Impact of the state Government budget on socioeconomic development of Assam", the comparison of budgeted target and actual achievement of the state Government has been made to interpret the implementation of budget and its affect on economic development.

Need for Study

The need for this study is to analyze how receipts and expenses are related .The specific need for this study is to analyze the allocation towards different sectors while preparing budgets and to analyze the trend of actual and estimates(increase or decrease) in the selected sectors.

Scope

The study covers 6 specific sectors in the expenditure budget (Defence, Agriculture, home affairs, Rural development, Railways, Education). The analysis is being carried out for past 3 years (i.e. 2017-18, 2018-19, 2019-20) correlation has been used to calculate the relation between the receipts and selected sectors in expenditure budget. Actual data has been collected for calculation.

Objectives

1. To calculate the trend in the union budget towards expenditure of selected sectors for last 5 years.

2. Compare the actual expenditure from the budgeted expenditure.

3. To analyze the overall revenue and allocation of expenses towards selected sectors in the Union budget.

Research Methodology

Secondary data has been collected from various websites, news paper articles, journals, lectures etc.

Objective 1.

\begin{tabular}{|l|l|l|l|l|l|l|l|}
\hline \multicolumn{7}{|l|}{ Trend analysis of Budgeted Estimates } \\
\hline $\begin{array}{l}\text { SL } \\
\text { No. }\end{array}$ & YEARS & DEFENCE & $\begin{array}{l}\text { HOME } \\
\text { AFFAIRS }\end{array}$ & AGRICULTURE & RAILWAYS & $\begin{array}{l}\text { RURAL } \\
\text { DEVELOPMENT }\end{array}$ & EDUCATION \\
\hline 1 & $2016-17$ & 100 & 100 & 100 & 100 & 100 & 100 \\
\hline 2 & $2017-18$ & 105.55 & 111.42 & 182.74 & 108.26 & 146.48 & 110.07 \\
\hline 3 & $2018-19$ & 118.61 & 142.98 & 184.69 & 122.75 & 130.93 & 117.43 \\
\hline 4 & $2019-20$ & 126.43 & 158.2 & 444.3 & 171.82 & 136.59 & 131.02 \\
\hline 5 & $2020-21$ & 138.27 & 222.3 & 457.76 & 181.33 & 139.46 & 137.18 \\
\hline
\end{tabular}

\begin{tabular}{|l|l|l|l|l|l|l|l|}
\hline \multicolumn{2}{|l|}{ Trend analysis of Actual Estimates } \\
\hline $\begin{array}{l}\text { SL } \\
\text { No. }\end{array}$ & Years & $\begin{array}{l}\text { DEFENC } \\
\text { E }\end{array}$ & $\begin{array}{l}\text { HOME } \\
\text { AFFAIRS }\end{array}$ & AGRICULTURE & RAILWAYS & $\begin{array}{l}\text { RURAL } \\
\text { DEVELOPMENT }\end{array}$ & EDUCATION \\
\hline 1 & $2016-17$ & 100 & 100 & 100 & 100 & 100 & 100 \\
\hline 2 & $2017-18$ & 107.94 & 110.75 & 92.23 & 92.76 & 114.06 & 11.38 \\
\hline 3 & $2018-19$ & 114.69 & 122.1 & 111.53 & 121.32 & 117.55 & 116.12 \\
\hline 4 & $2019-20$ & 128.78 & 146.91 & 211.7 & 142.22 & 128.76 & 124.19 \\
\hline 5 & $2020-21$ & 135.94 & 181.26 & 259.02 & 191.83 & 126.53 & 118.15 \\
\hline
\end{tabular}

The above tables show the trend analysis of Actual Estimates and Budgeted Estimates for last 5 years taking 2016-17 as a base year.

Objective 2

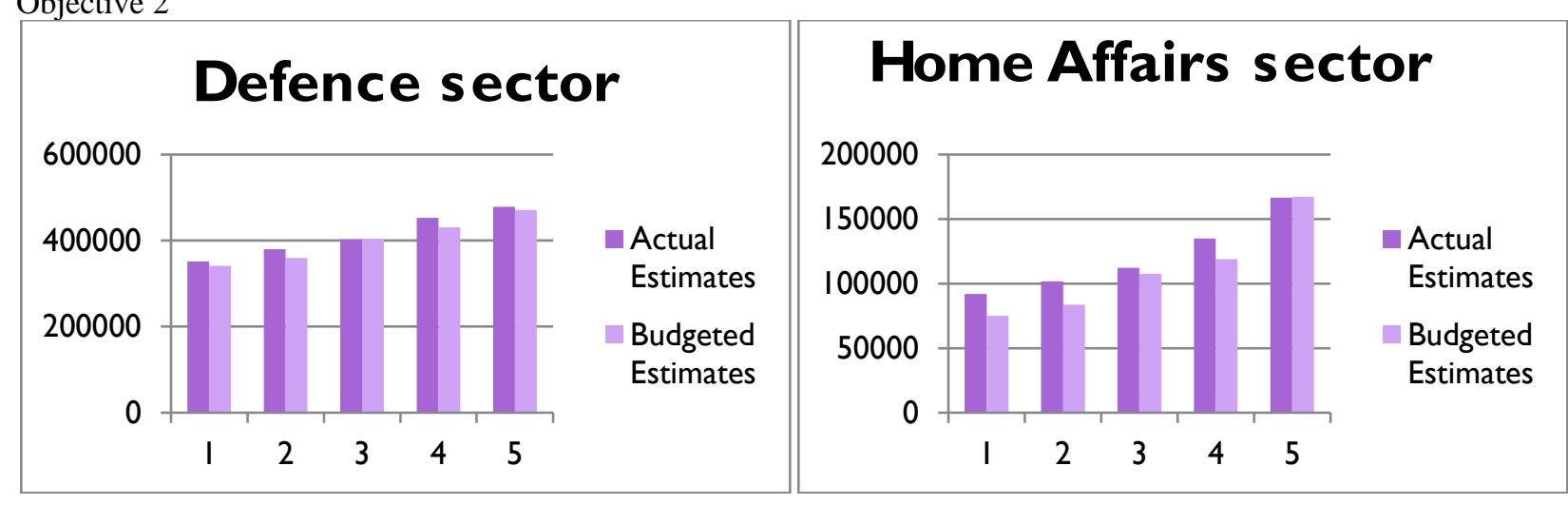


DOI: $10.17148 /$ IARJSET.2021.81105

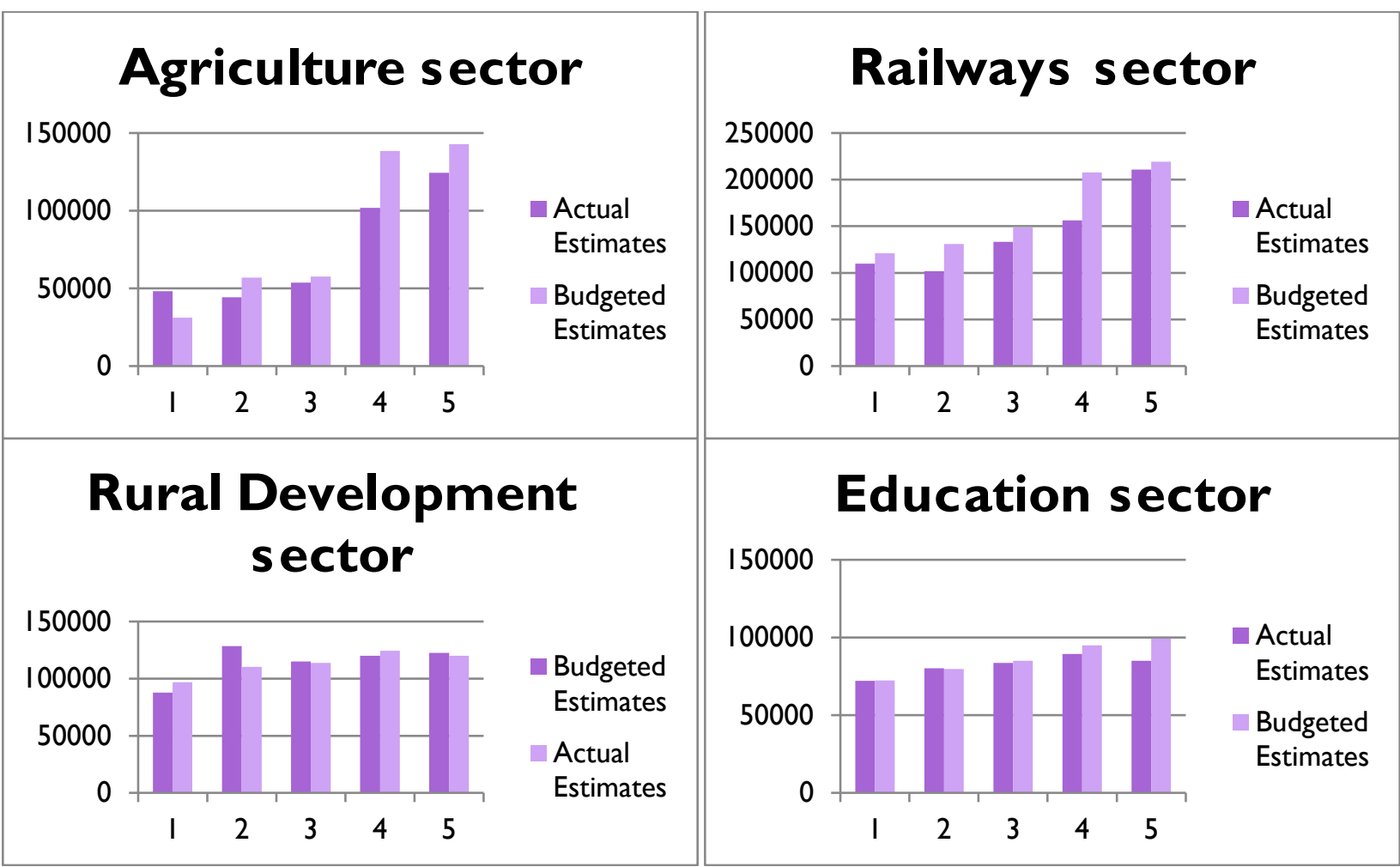

The above figures show the comparison between the actual estimates and budgeted estimates of different selected sectors for last 5 years.

Objective 3: Correlation Analysis

\begin{tabular}{|l|l|l|}
\hline Sectors & Correlation & Result \\
\hline Defence & $\mathbf{0 . 9 9 2 4}$ & Positively Strongly Correlated \\
\hline Home Affairs & $\mathbf{0 . 9 3 8 2}$ & Positively Strongly Correlated \\
\hline Agriculture & $\mathbf{0 . 8 3 0 9}$ & Positively Strongly Correlated \\
\hline Rural Development & $\mathbf{0 . 7 4 5 9}$ & Positively Moderately Correlated \\
\hline Railways & $\mathbf{0 . 9 4 6 2}$ & Positively Strongly Correlated \\
\hline Education & $\mathbf{0 . 6 3 1 1}$ & Positively Moderately Correlated \\
\hline
\end{tabular}

The above table shows the correlation analysis of the selected sectors for last 5 years. It has been observed that out of the selected sectors Defence sector has the highest allocation and the education sector is the least.

\section{CONCLUSIONS AND SUGGESTIONS}

All the sectors are having a increasing trend except the Rural development and Education sectors. Allocation to the Ministry of Agriculture and Farmers Welfare increased by $30.1 \%$ to Rs 1,42,762 crore in 2020-21 over the previous year. This is primarily due to an increase of Rs 20,630 crore in allocation to the PM-KISAN scheme. For Defence sector and Home affairs sector highest priority has been given because of pension's scheme. The allocation to the Railways sector is the second highest because Revenue sector has a revenue generation characteristics. The reason for the decline in Education sector is the delay in the implementation of new education policy and the closure of some rural education scheme in the rural areas.

\section{LIMITATIONS}

Of all the sectors available in the union budget only 6 major sectors are taken into consideration while calculating the allocation (The sectors which are selected will make a huge impact in the working of economy).

In depth analysis of every sector in expenditure budget has not been carried out.

In depth analysis of breakup of revenue and expenditure budget has not been done. 
International Advanced Research Journal in Science, Engineering and Technology

Vol. 8, Issue 11, November 2021

DOI: 10.17148/IARJSET.2021.81105

REFERENCES

1. https://www.wikiwand.com/en/Union budget of India

2. https://www.indiainfoline.com/article/news-union-budget/the-history-of-union-budget-118013000453_1.html

3. https://prsindia.org/budgets/parliament/demand-for-grants-2020-21-analysis-defence

4. https://www.mha.gov.in/about-us/about-the-ministry

5. https://thereaderwiki.com/en/Ministry of Home Affairs (India)

6. https://www.indiatvnews.com/business/news-budget-2020-ministries-with-highest-funds-allocated-defence-home-affairs-railways-top-10$\underline{585656}$

7. https://wiki2.org/en/Ministry of Agriculture and Farmers $\% 27$ Welfare

8. https://journalsofindia.com/agriculture-at-a-glance/ 